\title{
LAW AND TECHNOLOGY: THE CASE FOR A SMART GUN DETECTOR
}

\author{
SAM KAMIN*
}

\section{INTRODUCTION}

On March 10, 1995, the Justice Department announced the awarding of three grants totaling more than $\$ 2.15$ million for "the development of new high technology gun detectors" designed to detect concealed handguns. ${ }^{1}$ The grants have been hailed by law enforcement officials, politicians, and industry as a major step forward in crime prevention. Representative Charles Schumer's comments are typical: "This type of technology gives me more optimism about winning the war on crime than anything in the past two decades."2 While it is hoped that these technologies will improve the ability of law enforcement agencies to prevent gun violence, their constitutionality has already been questioned. $^{3}$

The emergence of these new technologies and the constitutional arguments they raise occasion a new look at the role the handgun has played in Fourth Amendment jurisprudence. For the last thirty years, courts have struggled with issues of weapons searches. Although they have been extremely wary of deviating from the constitutional requirement that a search may only be conducted pursuant to a warrant supported by probable cause, they have been mindful of the public's well-grounded fear of violence. Generally, fear has won. Beginning with the Supreme Court's decision in Terry v. Ohio, ${ }^{4}$ courts have grudgingly been willing to relax the requirements for conducting searches where the goal is the discovery of hidden weapons.

This article begins In Part II by briefly recounting the courts' treatment of weapons searches and examining the cases involving the need of police officers to protect themselves by searching suspects for weapons during street interrogations. These cases make three things readily apparent: (1) the decision to allow searches for weapons based upon less than probable cause is driven by the unique dangers that handguns pose to police officers conducting interrogations in the field; (2) the Supreme Court approved a "pat down" for weapons

\footnotetext{
Copyright $\odot 1996$ by Law and Contemporary Problems

* Judicial Clerk to the Honorable D. Lowell Jensen, Federal District Court for the Northern District of California.

1. Fox Butterfield, Justice Department Awards Grants to Develop Gun Detectors, N.Y. TIMES, Mar. 10, 1995, at A22.

2. Id.

3. Id.

4. 392 U.S. 1 (1968) (holding that a police officer may make a reasonable search for weapons without probable cause of a person believed to be armed and dangerous).
} 
because it was the least intrusive search that could reliably determine whether a suspect possesses a weapon; and (3) even during the most narrowly tailored search for weapons, other criminal evidence is quite often discovered.

Part III reviews the ever-growing literature on weapons searches in other public places-the point-of-entry searches now conducted everywhere from airports to schools to courthouses. Although these searches are conducted in very different contexts than those in the street interrogation cases, both sets of cases share the same basic pattern: Courts are carving out an exception to the probable cause requirement based on the unique dangers posed by concealed weapons; they are taking pains to ensure that the least invasive means available are used to detect these weapons; and, nonetheless, a large amount of other contraband is being detected. However, the one bit of new information these cases add is that courts are universally willing to allow this other contraband to be used as evidence against defendants, whether a gun was present or not.

Part IV demonstrates that, as the recent technological grants make clear, in this area of the law, doctrine and technology are inextricably linked. The problems with the current method of detecting handguns are as much a function of technology as of law; courts have had to permit searches by "pat downs," metal detectors, and x-ray machines based upon less than probable cause because they do not have any other options. Perhaps the problem is not with the "least invasive search" doctrine that the courts have adopted, but with the methods that are currently the least invasive means for detecting weapons.

Finally, Part V investigates technologies that may lead the courts out of the constitutional muddle in which they find themselves on the question of weapons detection. It describes those technologies that have recently been given grants and others that are already in use or development. While these technologies are certainly useful, they reveal that what is needed is a device that can reliably separate those carrying weapons from those who are not, without providing any other information about the individuals being screened. This hypothetical "smart detector" would not constitute a search under the Fourth Amendment and could provide law enforcement with probable cause to make a more invasive search. Because it would place searches for weapons back within the rubric of probable cause, this new technology could aid law enforcement in its ability to detect concealed weapons while at the same time protecting civil liberties. It would also have the added benefit of tidying up a messy bit of Fourth Amendment doctrine.

STREET INTERROGATIONS

The gun, and in particular the concealed handgun, assumed its place of prominence in Fourth Amendment jurisprudence in 1968 when the United 
States Supreme Court decided Terry v. Ohio. ${ }^{5}$ In Terry and its companion case, Sibron v. New York, ${ }^{6}$ the Court decided whether a police officer operating in the field could stop and frisk a suspect for weapons if the officer did not have probable cause to make an arrest. ${ }^{7}$

\section{A. Terry v. Ohio}

1. The Court's Ruling. The facts of Terry are by now quite familiar, but they bear a quick retelling here. Officer Martin McFadden watched Terry and two companions walk back and forth in front of a store peering into its windows for ten to twelve minutes. McFadden would later testify that he suspected the men of "casing a job, a stick-up" and feared they might have a gun. ${ }^{8}$ With his suspicions raised, McFadden approached the men, identified himself as a police officer, and asked for their names. When the only answer he received was a mumble, McFadden grabbed Terry, spun him around, and frisked him, running his hands over the outside of Terry's clothes. Detecting what he believed to be a weapon in Terry's coat pocket, the officer reached inside the coat and removed a gun. He then frisked the other two men, finding a gun on one of them, and removing it. Terry and his companion Chilton were arrested and charged with carrying concealed weapons. ${ }^{9}$

A search or seizure is conducted-and the Fourth Amendment is implicated-whenever an individual's reasonable expectation of privacy is invaded by a state actor. ${ }^{10}$ The first question for the Terry Court, therefore, was whether Terry had a reasonable expectation of privacy at the time he was stopped by McFadden. Based on the Court's decision earlier that term in Katz v. United States, ${ }^{11}$ this was a relatively easy question for the Court to answer. Katz had held that "the Fourth Amendment protects people, not places."12 In other words, the Fourth Amendment was designed not only to prohibit unreasonable searches of citizens' homes and possessions, but of their persons, wherever they might be. Thus, the Terry Court concluded, "[u]nquestionably the petitioner was entitled to the protection of the Fourth Amendment as he walked down the street in Cleveland." $" 13$

Similarly, the question of whether McFadden's actions interfered with Terry's reasonable expectation of privacy was easy for the Terry Court. The Court wrote,

5. Id.

6. 392 U.S. 40 (1968).

7. Terry, 392 U.S. at 10; Sibron, 392 U.S. at 58-61.

8. Terry, 392 U.S. at 6.

9. Id. at 7 .

10. Katz v. United States, 389 U.S. 347, 361 (1967).

11. 389 U.S. 347 (1967).

12. Id. at 351.

13. Terry, 392 U.S. at 9. 
It must be recognized that whenever a police officer accosts an individual and restrains his freedom to walk away, he has seized that person. And it is nothing less than sheer torture of the English language to suggest that a careful exploration of the outer surfaces of a person's clothing all over his or her body in an attempt to find weapons is not a search. ${ }^{14}$

Therefore, because Officer McFadden violated Terry's reasonable expectation of privacy, the Court concluded his actions must comply with the Fourth Amendment or the fruits of his search must be suppressed. ${ }^{15}$ The Fourth Amendment reads: "The rights of the people to be secure in their persons, houses, papers, and effects, against unreasonable searches and seizures, shall not be violated, and no Warrants shall issues, but upon probable cause . ..."16 The Constitution therefore prohibits both unreasonable searches and seizures and warrants issued without probable cause. ${ }^{17}$ In Terry, the Court determined that street interrogation "historically has not been and as a practical matter could not be, subjected to the warrant procedure." 18 Stops and frisks, therefore, are to be upheld or rejected based upon their reasonableness and not based upon whether or not a warrant was properly issued for the stop and seizure. ${ }^{19}$

To determine the reasonableness of searches conducted during street interrogations, the Court followed the test it had previously established in Camara v. Municipal Court ${ }^{20}$ by "[b]alancing the need to search (or seize) against the invasion which the search or seizure entails." ${ }^{21}$ Furthermore, the Court argued, no search can be justified unless the police officer can "point to specific and articulable facts which, taken together with rational inferences from those facts, reasonably warrant that intrusion." 22 Not only must a search be reasonable when instigated, but also the methods must be reasonably related to the goal. Turning to the facts of the case before it, the Court held that "[i]t would be poor police work indeed" for an officer of McFadden's experience not to intervene after observing the behavior of Terry and his companions. ${ }^{23}$ The question for the Court, therefore, was whether McFadden was justified in frisking the suspects for weapons once he approached them for questioning.

14. Id. at 16.

15. Mapp v. Ohio, 367 U.S. 643 (1961) (finding that evidence obtained in unconstitutional searches and seizures is inadmissible in a state court criminal trial).

16. U.S. CONST. amend. IV.

17. From the amendment's inception, there has been debate about the relationship between its two clauses. For example, must a search conducted in the absence of a warrant meet the probable cause requirement? When does a search require a warrant? See 3 WAYNE R. LAFAVE, SEARCH AND SEIZURE $\S 9.1$ (d), at 340-45 (2d ed. 1987). Professor LaFave argues that this ambiguity results from an error in the process of redrafting the amendment. See also Comment, Search and Seizure in the Supreme Court, 28 U. CHI. L. REV. 664 (1961).

18. Terry v. Ohio, 392 U.S. 1, 20 (1968).

19. Id.

20. 387 U.S. 523 (1967).

21. Terry, 392 U.S. at 21 (quoting Camara, 387 U.S. at 536-37).

22. Id.

23. Id at 23 . 
While acknowledging the serious privacy invasion of even a quick frisk for weapons, ${ }^{24}$ the Court concluded that "it would be clearly unreasonable to deny the officer the power to take necessary measures to determine whether the person is in fact carrying a weapon and to neutralize the threat of physical harm."25

The result in Terry was a significant deviation from earlier rulings that the requirements for a search conducted in the absence of a warrant were at least as stringent as those required for a warrant. ${ }^{26}$ Justice Douglas noted this change in his dissent, arguing that the Court's decision gives police "greater authority to make a 'seizure' and conduct a 'search' than a judge has to authorize such action." 27 Nonetheless, the Court, propelled by a desire to protect officers from the dangers posed by concealed handguns, carved out an exception to its longstanding precedents which articulated a stricter standard for searches.

2. Implications of Terry. Two aspects of the Court's opinion in Terry are important to the Fourth Amendment implications of emerging weapons technology. The first is that the Court's decision to allow searches based upon less than probable cause was motivated by a justifiable fear for the safety of officers. It is clear that law enforcement officers should be able to stop briefiy and question those whom they suspect of having committed a crime. Furthermore, the facts of Terry make clear how dangerous such stops can be for police officers: The exigencies of his job forced Officer McFadden, without any backup, to confront three individuals he suspected of plotting an armed robbery. Under these circumstances, the Court rightly concluded that an officer must be able to take some steps to protect himself from the danger posed by possibly armed assailants. ${ }^{28}$

In reaching this conclusion, the Court was aware of the tension between two competing interests that exist in the area of street interrogations.

On the one hand, it is frequently argued that in dealing with the rapidly unfolding and often dangerous situations on city streets, the police are in need of an escalating set of flexible responses, graduated in relation to the amount of information they possess. ...

On the other side, the argument is made that the authority of the police must be strictly circumscribed by the law of arrest and search as it has developed to date in the traditional jurisprudence of the Fourth Amendment. ${ }^{29}$

The Court grudgingly decided in favor of the former. The rhetoric of Terry manifests an awareness of the risks armed criminals can pose to officers

24. Id. at 24-25 ("Even a limited search of the outer clothing for weapons constitutes a severe, though brief, intrusion upon cherished personal security, and it must surely be an annoying frightening, and perhaps humiliating experience.").

25. Id. at 24.

26. See Wong Sun v. U.S., 371 U.S. 471 (1963).

27. Terry, 392 U.S. at 36 (Douglas, J., dissenting).

28. Id. at 10,11 .

29. Id. at 23-24. 
attempting to apprehend them. At one point, the Court noted that "American criminals have a long tradition of armed violence, and every year in this country many law enforcement officers are killed in the line of duty, and thousands more are wounded. Virtually all of these deaths, and a substantial portion of the injuries, are inflicted with guns and knives." ${ }^{30}$ Led by this concern for the inherent risks facing a police officer and by a desire to protect the officer from unnecessary risks, the Court allowed an exception to the rule that "the police must, whenever practicable, obtain advance judicial approval of searches and seizures through the warrant procedure." ${ }^{31}$ As discussed in the next section, however, the Court took steps to ensure that the exception it crafted to the probable cause requirement was limited.

The other important aspect of the Terry decision is a corollary of the first: The search for weapons is justified on narrow grounds; therefore, the search which is authorized must be similarly narrow in scope. The Court deemed the pat-down to be a reasonable search for weapons because it is the least intrusive means by which the police can reliably determine whether a suspect is carrying a gun. Although the Court was aware that even a quick pat-down is an invasive search, which might arouse both indignation and embarrassment on the part of the suspect ${ }^{32}$ and could easily be used to annoy and harass certain groups of the population, ${ }^{33}$ there was no less invasive means available. Ultimately, although the Court sided with officers on the street by allowing protective searches for weapons, it limited the holding by permitting only the narrowest of possible searches.

The narrow search requirement is illustrated by the Terry decision itself. The Court assured itself that Officer McFadden conducted the least invasive search necessary to determine whether Terry and his companions carried weapons. For example, the majority noted that McFadden reached into the pockets of Terry and Chilton only after feeling what he believed to be guns while frisking them. Finding no such suspicious bulges in the third suspect's pockets, he did not continue his search by reaching inside his outer clothing after patting him down. Officer McFadden, "confined his search strictly to what was minimally necessary to discover if" Terry and his companions were armed. $^{34}$

30. Id. (citing statistics that 41 of 57 officers killed in 1966 were slain by criminals using concealed handguns).

31. Id. at 20.

32. As the Court put it,

[It] is simply fantastic to urge that such a procedure performed in public by a policeman while the citizen stands helpless, perhaps facing a wall with his hands raised, is a "petty indignity." It is a serious intrusion upon the sanctity of the person, which may inflict great indignity and arouse strong resentment, and it is not to be undertaken lightly.

Id. at 16

33. Id. at 14 .

34. Id. at 30 . 


\section{B. Sibron v. New York and Peters v. New York}

The Court's decision in Terry provided only general guidelines. Rather than stating hard and fast rules for protective searches, the Court held that " $[\mathrm{t}] \mathrm{hese}$ limitations will have to be developed in the concrete factual circumstances of individual cases." 35 The same day Terry was decided, the Court also decided two other street interrogation cases, Sibron $v$. New York and Peters v. New York. ${ }^{36}$ The analysis in these cases helps to flesh out the skeletal ruling in Terry. ${ }^{37}$

1. The Holdings. In Sibron, a New York City police officer observed the defendant over an eight-hour period in conversation with a number of known narcotics addicts. At the end of this period, the officer walked up to the defendant in a restaurant, took him outside, announced "You know what I'm after," and reached into defendant's pocket where he discovered a vial of heroin. The Court invalidated the search and suppressed the heroin on a number of grounds. First, the Court rejected the proposition that Sibron's mere act of speaking with known narcotics addicts gave the officer probable cause to arrest Sibron and search him pursuant to that arrest. ${ }^{38}$ Second, the search could not be justified on Terry grounds, because the officer's statement made it clear that he was looking not for a weapon but for heroin. ${ }^{39}$ Finally, even assuming that the officer's statement could imply that he was looking for weapons rather than drugs, the search that he conducted was not consistent with the minimum "pat down" for weapons permitted in Terry: The officer reached immediately into Sibron's pocket without first patting him down to determine whether the suspect had a gun. As the Court phrased it,

[t]he search for weapons approved in Terry consisted solely of a limited patting of the outer clothing of the suspect for concealed objects which might be used as instruments of assault .... In this case, with no attempt at an initial limited

35. Id. at 29.

36. Both reported in Sibron v. New York, 392 U.S. 40 (1968).

37. Although the parties in Sibron and Peters briefed the issue before the Court as the facial constitutionality of a New York statute permitting the police to stop-and-frisk suspects, the Supreme Court decided to rule on the individual circumstances of the searches involved. Id. at 59 ("The constitutional validity of a warrantless search is pre-eminently the sort of question which can only be decided in the concrete factual context of the individual case.").

38. Id. at 62-63.

39. Justice Harlan, concurring in the result, argued that in deciding Sibron, the Court deviated from the rationale of Terry. For Harlan, not only did the officer lack probable cause to arrest the defendant, he did not have specific and articulable facts to suspect that Sibron was engaged in crime. After eight hours of surveillance, the defendant had done nothing to suggest that he was engaged in crime other than consort with known addicts. Since he was not entitled to stop him, the officer could not frisk him. In deciding the case at this level, Harlan argued, he is spared a difficult decision. For Harlan, Terry established the proposition that the "right to frisk is automatic when an officer lawfully stops a person suspected of a crime whose nature creates a substantial likelihood that he is armed." Id. at 74 (Harlan, J., concurring) (emphasis added). The question here is whether "suspected possession of narcotics" falls into this category. 
exploration for arms, [the officer] thrust his hand into Sibron's pocket and took from him envelopes of heroin. ${ }^{40}$

In Peters, an off-duty police officer heard noises in his hallway, and upon investigating, discovered two men tiptoeing down the hall. Believing that the men were planning a burglary, the officer called for backup and then entered the hallway to confront the two men. The men fled with the officer in chase. Upon catching one of the men, Peters, the officer patted him down, and felt what he believed to be a knife in the suspect's pocket. When he reached into the pocket to remove this object, however, the officer discovered not a knife, but a case containing burglar's tools. Peters was convicted of possessing the tools, a felony in New York. The Court decided that although these facts might support a finding that the officer had conducted a legitimate protective search, the search conducted was justified, not on the grounds of Terry, but as a search incident to a lawful arrest. ${ }^{41}$ The combination of the furtive behavior the officer observed in the hallway and the flight of the suspects from his presence, the Court concluded, gave the officer grounds upon which to arrest the men for burglary. ${ }^{42}$

2. The Importance of Sibron and Peters. What do these cases add to the Terry holding? For one thing, Sibron shows that Terry was based solely on the need to protect the officer and the public from concealed weapons and not to aid police in looking for evidence of criminal activity. Sibron's conviction was overturned both because the Court did not believe that the officer conducted a search out of a genuine fear for his safety and because, even had the officer been so motivated, he had not conducted the minimal search necessary to achieve that end.

Furthermore, Peters, although decided on the basis of a search incident to a lawful arrest and not on the rationale of Terry, shows that even narrow searches for weapons will turn up other evidence of criminal activity. Officer Lasky conducted a search in Peters very similar to the one Officer McFadden performed in Terry. He first felt the exterior of the suspect's clothing, and only once he discovered what he thought to be a weapon did he reach inside to remove the object. While he did not find the weapon that he was looking for, he did discover evidence that served to convict Peters of another crime.

Sibron and Peters also make clear that there is another reason for limiting the nature of the searches that can be conducted, namely the danger that law

40. Id. at 65 .

41. Id. at 66 .

42. In his concurrence, Justice Harlan strongly disagreed with the Court on the question of whether the officer had grounds to make an arrest at the time he searched Peters: "I do not think that Officer Lasky had anything close to probable cause to arrest Peters before he recovered the burglar's tools." Id. at 74 (Harlan, J., concurring). Harlan would have upheld the search as a valid protective search, following the rationale of Terry. Id. at 77-78. 
enforcement will use the search for weapons as a subterfuge to find contraband. ${ }^{43}$ While the Court did not protect individuals from the indignity associated with pat down searches, it did offer the promise that such searches would be permitted in only the narrowest of circumstances. The pat down must remain a search for weapons; an officer cannot "conduct a general exploratory search for whatever evidence of criminal activity he might find." 44

Finally, it is worth noting that the Court has never squarely faced the question of whether contraband other than weapons discovered during a protective search should be admissible as evidence. Because Terry was prosecuted for possessing the gun for which Officer McFadden searched him, the heroin discovered on Sibron's person was excluded, and the burglar's tools found on Peters's person were allowed into evidence only because they were discovered during a search incident to an arrest, the Court was not confronted with the question of whether contraband other than weapons discovered during a protective search for weapons should be admissible against a defendant. Thus far, only the lower courts have decided this question, and they have unanimously decided it in the affirmative. ${ }^{45}$

III

\section{POINT-OF-ENTRY SEARCHES FOR WEAPONS}

An exception to the probable cause requirement has also been made for weapons searches conducted in a very different context: point-of-entry searches in buildings open to the public. While protective street searches are justified by the concern for police officer safety, point-of-entry, or administrative, searches are based on a concern for public safety. This section examines how courts have created this exception and points out the similarity in logic between these cases and the Terry line of cases.

\section{A. Airports}

Spurred by an unprecedented increase in the incidence of hijackings in the United States, the Federal Aviation Administration (the "FAA") began regulating passenger access to flights in $1968 .^{46}$ As a result of the findings of its Task Force on Deterrence of Air Piracy, the FAA promulgated a voluntary

43. Although neither Sibron nor Peters directly implicates pretextual searches for weapons, both raise the specter. Sibron is an instance of the Court telling law enforcement that Terry was about safety, not crime detection. Peters simply showed that searches for weapons could easily turn up contraband.

44. Sibron, 392 U.S. at 30.

45. See infra text accompanying notes $92-96$.

46. For a good history of hijacking in the United States and FAA responses, see 3 LAFAVE, supra note 17 at 340-45; Sanford L. Dow, Comment, Airport Security, Terrorism, and the Fourth Amendment: A Look Back and a Step Forward, 58 J. AIR L. \& COM. 1149 (1993); Note, Searches for Hijackers, 40 U. CHI. L. REV. 383 (1973). 
policy that called for the use of metal detectors (magnetometers) ${ }^{47}$ coupled with a psychological profile to identify potential hijackers. Under this policy, ticket agents would surreptitiously mark the tickets of those passengers meeting a number of the criteria of the profile. ${ }^{48}$ At the boarding gate, all passengers were forced to walk through a magnetometer, but only profile selectees who set off the detector were detained for further investigation. If detainees could produce identification to airport security, however, they were free to board without further searches. If they could not, a deputy U.S. Marshal was summoned who either sought identification, asked the detainee to pass through the detestor after emntvino his nockets. nr asked the detaines. to submit to a 
after passengers had been screened according to the voluntary FAA policy. ${ }^{53}$ It came as no surprise, therefore, that in January of 1970 the FAA instituted a policy requiring all airlines to devise security systems "acceptable to the Administrator." 54 While mandating no particular security system, the FAA observed that the profile and magnetometer method had been effective where used. $^{55}$ Despite the fact that the second half of 1972 saw fewer hijacking attempts than any six-month period in the previous five years, ${ }^{56}$ in January of 1973 the FAA mandated the screening policy that has remained in place until today. All passengers and all packages to which they have access during flight must be electronically screened prior to boarding.

As the FAA-mandated blanket screening came into full use in 1973, new constitutional rationales for the system had to be found, a fact illustrated in United States v. Davis, ${ }^{57}$ where the Ninth Circuit held the following:

Terry, Sibron, and Adams ${ }^{58}$ are inapposite because [the airport official] had no particular interest in appellant as an individual. He had no individualized basis for the search at all, much less specific and articulable facts that would justify a reasonably prudent man in believing that appellant was about to commit a crime or that he was carrying a weapon. ${ }^{59}$

Courts have adopted a number of different approaches to justify these searches.

The most common justification for blanket airport searches invokes the rationale of administrative searches. ${ }^{60}$ Typical of these cases is Davis, in which the Ninth Circuit upheld the screening of all passengers on the basis of the enormous risks to life and property if the means necessary to hijack a plane are smuggled on board. The court went on to hold, however, that "an administrative screening search must be limited in its intrusiveness." purpose is to deter hijackers and not to arrest them, a person suspected of being a hijacker must have the right to walk away and resist further searches once the suspicion of law enforcement has been aroused.

In the Fifth Circuit and elsewhere, courts have upheld searches at airports by analogy to searches conducted at the U.S. border. ${ }^{62}$ Typical of these decisions is United States v. Skipwith, in which the court held that "the standards

53. U.S. DEP'T OF TRANSPORTATION NEWS, June 15, 1970, at 2.

54. 37 Fed. Reg. 2500 (1972).

55. Note, supra note 46 , at 391 .

56. Id.

57. 482 F.2d 893 (9th Cir. 1973).

58. Adams v. Williams, 407 U.S. 143 (1972) (ruling that policeman who discovered heroin on respondent had reasonable grounds to conduct the search after having already found a gun during an initial search based on a tip).

59. Davis, 482 F.2d at 907.

60. In Camara v. Municipal Court, 387 U.S. 523 (1967) and See v. City of Seattle, 387 U.S. 541 (1967), the Supreme Court permitted administrative searches to be conducted in the absence of probable cause where society's interest in conducting the searches outweighs the individual's privacy interest.

61. Davis, 482 F.2d at 910.

62. See U.S. v. Skipwith 482 F.2d 1272 (5th Cir. 1973); U.S. v. Legato 480 F.2d 408 (5th Cir. 1973); U.S. v. Moreno, 475 F.2d 44 (5th Cir. 1973). 
for initiating a search of a person at the boarding gate should be no more stringent than those applied in border crossing situations." ${ }^{163}$ When passengers present themselves for entry onto a plane or into a controlled area leading to a plane, the Skipwith court held, they, "like those seeking entrance into the country, are subject to a search based on mere or unsupported suspicion."

Finally, some courts have upheld airport searches on the grounds that those searched implicitly consented to be searched. A search that would normally violate the Fourth Amendment is valid if the person being searched voluntarily consents to the search. ${ }^{65}$ After the Supreme Court's decision in Schneckloth $v$. Bustamonte, ${ }^{66}$ the voluntariness of the consent to search is judged not based upon whether the defendant knew that he had the right to refuse, but rather whether consent can be implied from the totality of the circumstances. Although explicit consent is rarely given in airport search cases, a number of courts have implied consent to search from the circumstances of airport searches. For example, in United States v. Miner, ${ }^{67}$ the Ninth Circuit held that because the defendant "admitted that he had flown six or seven times before, that he had seen signs warning that all passengers and their baggage were subject to search,"68 and nonetheless attempted to board the plane, he implicitly consented to be searched.

\section{B. Other Public Place Searches}

Nearly all Americans are familiar with the searches that have become prerequisites for flying by air in the United States. One recent estimate is that more than one billion airline tickets were bought in the United States last year, approximately four for every man, woman, and child in the country. ${ }^{69}$ Each one of these persons is subject to such searches. More and more, however, Americans are becoming increasingly aware that airports are not the only public spaces in which they are subject to searches for weapons. As a result of violent incidents at courthouses, schools, and other public places, entry to a number of

63. Skipwith, 482 F.2d at 1276 . The court cites one border case as standing for the proposition that "[t]he fact that one is in the process of crossing an international boundary provides sufficient reason in itself to permit a search for aliens or contraband without the presence of any other circumstances that would normally have to attend the requirements of the Fourth Amendment." Id. at $1275 \mathrm{n} .3$ (quoting US v. McDaniel, 463 F.2d 129, 132 (5th Cir. 1972)).

64. Id at 1276.

65. But see Johnson v. United States, 333 U.S. 10 (1948) (ruling that consent to search is an invalid waiver of constitutional rights when police force their way into residence without probable cause); Amos v. United States, 255 U.S. 313 (1921) (wife's voluntary consent to search not binding on husband); Gaioni v. Folmer, 460 F. Supp. 10 (M.D. Ala. 1978) (conditioning access to a public forum on consent to an otherwise unreasonable search violates the fourth amendment).

66. 412 U.S. 218 (1973).

67. 484 F.2d 1075 (9th Cir. 1973).

68. Id. at 1076 .

69. United States v. $\$ 124,550$ U.S. Currency, 873 F.2d 1240 (1989) (citing UNITED STATES DEPARTMENT OF COMMERCE, STATISTICAL ABSTRACT OF THE UNITED STATES 7 (1988)). 
other public buildings is now conditioned upon submitting to a search for weapons. ${ }^{70}$

Although these cases have not generated nearly the volume of case law that airport searches have ${ }^{71}$ there is clear case law establishing the legitimacy of these searches. Generally, the courts follow a pattern similar to the Ninth Circuit's in McMorris v. Alioto. ${ }^{72}$ In McMorris, an attorney sought injunctive relief against the search procedures instituted at the San Francisco Hall of Justice, which contained the city's police department and the county court. The court began by citing airport search cases for the proposition that the warrant requirement exists for "limited searches of persons seeking to enter sensitive facilities."73 The court then opined that "threats of violent acts directed at courthouses have given rise to an urgent need for protective measures," ${ }^{, 74}$ and extended the exception to include courthouses.

While searches conducted as a requirement for entering courthouses have been upheld, broad searches at publicly owned auditoriums or arenas have not. Courts have held that these searches, often conducted to look for alcohol or drugs rather than weapons, do not have a sufficient government interest to justify the intrusion. For example, in Wheaton v. Hagan ${ }^{75}$ the court held that none of the exceptions to the warrant requirement were met in a program of random searches instituted at a municipally owned coliseum.

Finally, although no cases have tested them yet, magnetometer searches of students entering public schools are likely to be upheld by the courts. The Supreme Court held in New Jersey v. T.L.O. ${ }^{76}$ that the warrant requirement would "unduly interfere with the maintenance of the swift and informal disciplinary procedures [that are] needed." 77 In doing so, the Court hinted that, although it was permitting a search based solely upon individualized suspicion, it was willing to go even further: "[T]he Fourth Amendment imposes no irreducible requirement of such suspicion."78 The Court made good on this hint in 1995 in its decision in Vernonia School District 47J v. Acton. ${ }^{79}$ In that case, the Court upheld random drug testing of high school students participating in interscholastic sports. The testing permitted in Vernonia was much more

70. See Russell J. Davis, Annotation, Validity Under Federal Constitution of Search and Seizure Conducted as a Condition of Entering a Public Building, 53 A.L.R. FED. 888 (1981) (citing cases).

71. LAFAVE, supra note $17, \S 10.7$, at 37.

72. 567 F.2d 897 (9th Cir. 1978).

73. Id. at 899 .

74. $I d$.

75. 435 F. Supp. 1134 (M.D.N.C. 1977).

76. 469 U.S. 325 (1985).

77. Id. at 340 .

78. Id. at $342 \mathrm{n} .8$.

79. 115 S. Ct. 2386 (1995). 
invasive than a metal detector search, ${ }^{80}$ leaving little doubt that the Supreme Court remains ready to approve such searches if it is called upon to do so.

\section{The Importance of Public Place Searches}

Courts' attempts to fashion a constitutional justification for searches conducted in airports and other public places have received relatively mixed reviews. Commentators have criticized each of the justifications offered for searches conducted in public. ${ }^{81}$ Regardless of the efficacy of these methods, however, they reveal a number of interesting parallels to the way the Court handled weapons searches in Terry.

1. Narrow Purpose for Searches. As with Terry, courts deciding public place cases have made it quite clear that they are allowing searches for weapons purely to ensure the safety of those using public facilities. This is true of Davis, ${ }^{82}$ which permitted an airport search as a valid administrative search, of McMorris ${ }^{83}$ which permitted a courthouse search in light of bomb threats, and of Lopez ${ }^{84}$ which upheld the use of the profile/magnetometer system to screen hijackers. In each case, the court took pains to point out that it was permitting searches for weapons only. ${ }^{85}$

However, the arena cases make clear that the analogy to Terry and the airport and courthouse cases is inapposite because arena searches are motivated by a desire to keep not only weapons but contraband generally out of municipal arenas. As the court in Wheaton put it:

[U]nlike the searches in the stop-and-frisk situation or in the airport and courthouse settings, the policy in force at the Coliseum is not limited to searches for inherently lethal weapons. The policy also seeks to uncover other items of contraband including controlled substances, tape recorders, cameras, and alcoholic beverages. Clearly Terry $v$. Ohio does not sanction wholesale searches of the general public in the absence of exigent circumstances, even though the officials doing the searching have a valid interest in preventing potential injuries. ${ }^{86}$

80. As Justice Scalia described in his opinion, the testing of the student athletes is conducted by an adult monitor who watches and listens to the production of a urine sample and then checks the sample for temperature and tampering. Id. at 2389.

81. See, e.g., LAFAVE, supra note $17, \S 10.6(\mathrm{~g})$, at 31 ("It is submitted [that the implied consent approach] is basically unsound and in any event can hardly be employed, if the established standards of voluntary consent are followed, as a means of justifying all of the searches which are made in the screening process."); Note, Implied Consent in Airport Searches: A Response to Terrorism, United States v. Pulido Baquerizo, 800 F.2d 889 (9th Cir. 1986), 25 AM. CRIM. L. REV. 549, 560 (1988) ("It is poor judicial practice and extreme judicial activism to carve an entire sphere out of the confines of the Constitution simply because to do so would simplify law enforcement."); Note, The Constitutionality of Airport Searches, $72 \mathrm{MICH}$. L. REV. 128, 143 (1973) ("If the Camera rule were to be applied, the present airport serach system would not meet its standards.").

82. 482 F.2d 893 (9th Cir. 1973).

83. 567 F.2d 897 (9th Cir. 1978).

84. 328 F.Supp. 1077 (E.D.N.Y. 1971).

85. McMorris v. Alioto, 567 F.2d 897, 899 (9th Cir. 1978); United States v. Davis, 482 F.2d 893, 910 (9th Cir. 1973); United States v. Lopez, 328 F.Supp. 1077, 1097-98 (E.D.N.Y. 1971).

86. Wheaton v. Hagan, 435 F. Supp. 1134, 1146 (M.D.N.C. 1977). 
The court is making the argument that while contraband may cause security problems, these problems are not sufficiently severe to merit deviation from the warrant requirement.

2. Narrow Scope of Searches. Hand-in-hand with the requirement that searches be motivated by a desire to remove guns from public places is the requirement that searches be narrowly tailored to achieve this result. We can see this most clearly in the courts' decisions in the magnetometer/profile cases. There, courts approved a graduated search system similar to the one approved by the Supreme Court in Terry. Just as in Terry Officer McFadden searched the suspects in the least invasive method that was necessary to determine whether they were armed, so too in the airport context, searches were instituted in a gradual pattern of increasing invasiveness. Potential hijackers were first identified according to the profile, and then all passengers were made to walk through metal detectors. At that point, only those setting off the metal detector who had been selected using the profile were subject to further search. The limited nature of the search did not stop there, however; simply being a selectee who set off the magnetometer did not subject a passenger to a general search. If such a person were able to provide satisfactory identification, they were not detained or searched further. If they could not provide information, a federal marshal was summoned. The marshal would either ask again to see identification, or ask the detainee to remove the metal from his pockets and walk through the detector again. It was only if the detainee again set off the metal detector that he was asked to submit to a frisk or a search of his luggage or be denied access to the flight.

Similarly, the Second Circuit in United States v. Albarado ${ }^{87}$ approved a blanket search of all airline passengers but only so long as it was kept in mind that it is "a constitutional requirement that to be reasonable the search must be as limited as possible commensurate with the performance of its function." 88 With this in mind, the court concluded that permitting a frisk for weapons of all passengers who set off the magnetometer would be inefficient since by the court's measurement, fifty percent of all passengers activate the magnetometer. "It would be easier and more efficient merely to ask the passenger to remove all his metal items and return through the magnetometer." 89 The court also suggested that this technique is not the only one that would pass constitutional muster. For example, "[w]here airports are equipped with hand-held magnetometers, they may be used to locate metal on the passenger's body." 90 Whatever system is used, law enforcement must assure the court that the frisk "is to be used only in the last instance."

87. 495 F.2d 799 (2d Cir. 1974).

88. Id. at 806 (emphasis added).

89. Id. at 808 .

90. Id. at 809 .

91. Id 
3. Admissibility of Weapons Search By-Products. Finally, it should be pointed out that the courts of appeals have answered the question of whether other contraband discovered in the course of a search for weapons should be admissible against the defendant. And the answer is a resounding yes. One of the first courts to come to this conclusion was the Fifth Circuit in United States v. Skipwith. ${ }^{92}$ After concluding that the cocaine found on Skipwith was discovered during a valid search for weapons, the court was forced to decide whether the by-product of the search should be excluded on the ground that this "exclusion will destroy the incentive for officers to conduct pretextual searches." 93 The court concluded that "[t]his argument has never been accepted by any court," and echoed the language of Terry that the exclusionary rule cannot be applied to legitimate searches in order to deter illegitimate ones. ${ }^{94}$

The decision not to exclude search by-products is an important one because the discovery of contraband or other illegal activity is more frequent than the discovery of weapons. Almost all of the major cases that have tested the validity of public place searches have involved motions to suppress contraband other than guns. ${ }^{95}$ An early study of the FAA-mandated program revealed that only twenty percent of arrests arising out of airport searches were for weapons, while the plurality of arrests were for undocumented aliens. ${ }^{96}$

\section{IV}

\section{The Current State of the ART And the State of the LaW}

The damage that one handgun can do on a pressurized aircraft flying at 35,000 feet clearly justifies the scrutiny of all airline passengers and their belongings. While the danger that a handgun poses in a courthouse, school, or jail may be less dramatic, it is easy to understand why in the past several years a number of these institutions have also begun permitting access only to those who have been screened for weapons. These dangers are so apparent that most Americans seem willing to exchange the personal invasion of being searched for the peace of mind in knowing that all will be searched. One recently published study of the perceived invasion of privacy associated with different searches and

92. 482 F.2d 1272 (9th Cir. 1973).

93. Id. at 1278 .

94. Id.

95. See, e.g., United States v. $\$ 124,570$ U.S. Currency, 873 F.2d 1240 (9th Cir. 1989) (currency tainted with controlled substances); United States v. Pulido-Baquerizo, 800 F.2d 899 (9th Cir. 1986) (cocaine); United States v. Smith, 643 F.2d 942 (2d Cir. 1981) (currency); United States v. Albarado, 495 F.2d 799 (2d Cir. 1974) (counterfeit bills); United States v. Miner, 484 F.2d 1075 (9th Cir. 1973) (amphetamines); United States v. Skipwith, 482 F.2d 1272 (5th Cir. 1973) (cocaine); United States v. Moreno, 475 F.2d 44 (5th Cir. 1973) (heroin); United States v. Scott, 406 F.Supp. 443 (E.D. Mich. 1976) (cocaine); United States v. Lopez, 328 F.Supp. 1077 (E.D.N.Y. 1971) (heroin).

96. Hijacker Searches Lead to 1,500 Other Arrests, N.Y. TIMES, Nov. 2, 1973, at A1. According to the article, of 1,535 arrests made through October 8,1973, 526 were of illegal aliens, 443 were for possession of narcotics, 187 were for possession of firearms, and 99 were for possession of other weapons. 
seizures found that being made to walk through a magnetometer at an airport ranked forty-ninth out of fifty in terms of invasiveness. ${ }^{97}$

Furthermore, the current weapon detection system seems to be working; the armed takeover of airplanes in the United States has ceased to be a contemporary phenomenon. This does not mean that the abandonment of the airport screening has become a possibility; as the Second Circuit Court of Appeals reasoned in United States v. Albarado, "[w]hile the system was justified originally as a means to stop hijackings, now that it seems to be proven successful, its retention will be justified as necessary to stop their resurgence."98

Although the current technologies for detecting handguns protect the public from the dangers of concealed weapons at a relatively cheap cost in terms of privacy invasion, they are far from perfect. In both the street interrogation and point-of-entry search contexts, the deficiencies of the current technologies are plain and suggest the need for alternatives.

\section{A. Street Interrogations}

From the dawn of police work until the present, police had to stop and frisk those individuals they suspected of carrying weapons in order to determine whether they were in fact armed. As noted above, Terry v. Ohio ${ }^{99}$ established that where police officers have reasonable and articulable suspicion that an individual is armed, they may "conduct a carefully limited search of the outer clothing" to determine whether the individual is armed. ${ }^{100}$ Although Terry was originally designed to protect the officer and the public from confrontations with armed suspects, in fact, the protections it affords are relatively minor. In Terry, the officer was permitted to stop and pat down the three individuals he suspected of plotting an armed robbery. The fact that he was able to pat down one of the suspects while another suspect with a gun in his pocket watched is a testament to the officer's skill, but it points out the dangers that remain in the process. After Terry, officers were free to attempt to protect themselves and the public from armed suspects, but the manner in which they were permitted to do so continued to subject them to danger.

Similarly, the problems of abuse that the Court discussed in Terry remain with us. The stop-and-frisk, while narrowly tailored to find weapons, is far from a "petty indignity." The Court described the procedure as "a serious intrusion upon the sanctity of the person which may inflict great indignity and arouse strong resentment ...." It was a procedure, the Court stated "not to be undertaken lightly."101 Furthermore, if not properly monitored, the stop and

97. Christopher Slobogin \& Joseph E. Schumacher, Reasonable Expectations of Privacy and Autonomy in Fourth Amendment Cases: An Empirical Look at "Understandings Recognized and Permitted by Society," 42 DUKE L.J. 727, 737 (1993).

98. United States v. Albarado, 495 F.2d 799, 805 (2d Cir. 1974).

99. 392 U.S. 1 (1968).

100. Id. at 30.

101. Id. at 17. 
frisk can be directed at marginalized groups in order to harass and to threaten. As the Terry Court itself pointed out, so long as the police conduct frisks not with an eye toward prosecution but rather toward simple harassment, the exclusionary rule will serve no purpose in deterring discriminatory application of the "protective" search.

These faults in the Terry doctrine cannot be blamed on the Court, for it appears that the decision was the best balance available. As the Court correctly pointed out, it would be absurd to force police to wait until a crime has been committed before searching a suspect. Furthermore, the Court acknowledged that it would be unfair to ask law enforcement officers to approach suspicious persons but deny them the opportunity to determine whether those they encountered were armed. The problem was that in 1967 (as today) the only way for a police officer to determine whether an individual was armed was to approach the subject and put his hands on him. Thus, if there is a problem with the result in Terry, it can be solved not by changing the doctrine of the case but rather by changing the technologies available to law enforcement.

\section{B. Public Place Searches}

The expansion of the airport security system to other areas poses an inconvenience to all those attempting to gain access to protected buildings. The checkpoint searches may cause lengthy delays, as each person must stop to be searched. Also, because the magnetometer, the chief weapon at most checkpoints, is so easily set off by innocent items on one's person, a large number of people find themselves subject to the added invasion of being forced to empty their pockets and pass through the detector again, being searched with a handheld detector, or even being frisked if they continue to set off the electronic sensors. Yet, as has been mentioned above, most people seem more than willing to put up with these minor inconveniences. They are seen by most of the public as the cost of living in a dangerous society.

Far more damaging from a privacy standpoint, however, is the threat of subterfuge by law enforcement. So long as it is regulated to remain within the stated administrative purposes, the current system of public place searches may indeed be a justified intrusion. The problem is that these searches have not always been well tailored to find weapons. Courts have cracked down on some of the worst abuses of the system, but a number have survived.

Perhaps the most blatant ratification of a pretextural search is a district court's decision in the case of United States v. Scott. ${ }^{102}$ In that case, while maintaining that "courts must be vigilant in protecting against the abuse of [weapons searches] for collateral investigations," 103 the court permitted a search that was instigated at the request of a law enforcement officer conducting a collateral investigation. In Scott, the defendant was followed to an airport by

102. 406 F. Supp. 443 (E.D. Mich. 1976).

103. Id. at $444-45$. 
a D.E.A. agent who suspected he was carrying narcotics. The agent informed the security guard operating the $x$-ray scanner at the gate that "defendant had been seen with large sums of money" and requested that the operator "be particularly observant if [he] should have a legal reason to search defendant's luggage."104 The $x$-ray operator conducted a hand search of the bag after detecting a mass on the $\mathrm{x}$-ray that he testified might have been a knife or a gun. The mass was in fact the cocaine for which the D.E.A. agent had been looking.

This ruling is particularly disturbing because almost anyone has a piece of metal on their person that could set off a magnetometer or has an opaque object in their luggage that could arouse the suspicions of an $\mathrm{x}$-ray attendant looking for a legal excuse to stop someone. To allow searches after law enforcement officials tell operators which suspects they would like to search is to give law enforcement the opportunity to conduct searches they would not otherwise be permitted to conduct.

While Scott is the exception and not the rule, it is not entirely aberrational. For example, in United States v. Smith, ${ }^{105}$ the Second Circuit upheld the search of a carry-on bag by a security officer who had been informed by a D.E.A. agent that the suspect was under investigation and that "it would be helpful if security personnel could obtain serial numbers from the bills" the suspect was carrying. ${ }^{106}$ The security officer detected a mass on the $\mathrm{x}$-ray screen that "had the shape of a plastic explosive" and opened the suitcase discovering the money which the D.E.A. agent had mentioned. ${ }^{107}$ Similarly, in Shapiro v. State, ${ }^{108}$ a narcotics detective who was investigating the defendant followed the defendant to his gate and watched as his luggage was passed through the $\mathrm{x}$-ray machine. After the defendant was cleared by the security officers at the gate, the detective identified a "a gray mass," which could have been plastic explosives, in the defendant's suitcase. The officer reached into the defendant's suitcase and withdrew what turned out to be a package containing 6.5 pounds of cocaine. ${ }^{109}$ The constitutionality of both searches was upheld. ${ }^{10}$

As in the street context, the difficulty that courts have had in fashioning narrow permissible grounds for public place searches may not be a result of the court's failure to find the proper doctrine. The problem, rather, is that until

\footnotetext{
104. Id. at 444 .

105. 643 F.2d 942 (2d Cir. 1981) (citing Scott favorably).

106. Id. at 943 .

107. Id. at $943-44$

108. 390 So.2d 344 (Fla. 1980).

109. Id. at 346 .

110. The proliferation of plastic explosives as a tool of terrorists has had particularly troubling civil liberties consequences. Both Shapiro and Smith involved searches conducted because a mass within a package or suitcase "looked like plastic explosives." While the threat of plastic explosives to air safety is no doubt a real one, the argument that a package should be subject to hand search because its contents might contain plastic explosives is absurd. The very point of plastic explosives is that they are pliable; they can be formed into whatever shape fits the needs of the user. To allow the detection of a dark mass on an $x$-ray which might be plastic explosives to be the basis of a more invasive search is, therefore, to permit the hand search of all baggage.
} 
recently scientists and engineers have not been encouraged to provide law enforcement with the proper technology to do the job. If the goal is to keep guns out of our public places, it will always be necessary to determine whether each person attempting to enter the protected area is carrying a gun. In most cases, the primary means of searching for weapons are exactly the same as they were twenty-five years ago when Terry was decided or twenty years ago when the Davis decision was handed down. Police looking for weapons on a suspect pat the person down; security personnel monitoring an entrance use metal detectors and $\mathrm{x}$-ray machines backed up by the possibility of frisks. These detection methods are "dumb." They turn up not only weapons but anything that either feels like a weapon through clothes, contains enough metal to set off a metal detector, or has a profile that looks enough like a weapon to alert an $\mathrm{x}$-ray technician. As we have seen, this profile fits a wide array of items, both innocent and contraband. ${ }^{111}$

\section{Possible Solution-A Smart Gun Detector}

If the problem with the current state of weapons searches is that the technologies which exist to detect weapons are "dumb," what is needed is a "smart" detector-one that can be used to detect only weapons without revealing any additional information about an individual. Such a detector would prove to be a win-win situation. It would decrease the number of false positives-those people wrongly indicated as possessing weapons-while at the same time it would minimize the intrusion on the privacy of those members of the public not carrying weapons. Such a system would be rare indeed, as it would benefit law enforcement in their search for weapons, and, at the same time, it would minimize the invasion of civil liberties.

A smart detector has appeared several times before in Fourth Amendment jurisprudence. One example is the canine sniff, in which a dog that has been trained to recognize the smell of narcotics is allowed to sniff individuals' belongings in schools, airports, and other public places. The Supreme Court determined in United States $v$. Place ${ }^{112}$ that the use of a trained dog does not constitute a search because the luggage is not opened and exposed to public view.

Moreover, the sniff discloses only the presence or absence of narcotics, a contraband item. Thus, despite the fact that the sniff tells the authorities something about the contents of the luggage, the information obtained is limited. This limited disclosure also ensures that the owner of the property is not subjected to the embarrassment and inconvenience entailed in less discriminate and more intrusive investigative methods.

In these respects, the canine sniff is sui generis. We are aware of no other investigative procedure that is so limited both in the manner in which the information is obtained and in the content of the information revealed by the procedure. ${ }^{113}$

111. See supra text accompanying notes 102-10.

112. 462 U.S. 696 (1983).

113. Id. at 707. 
Thus, using drug sniffing dogs to search luggage is not a search under the Fourth Amendment.

Only a person carrying contraband, the Court stated, could object to the use of a canine sniff, since no other invasion of privacy is involved in the procedure. ${ }^{114}$ This is in fact a good working definition of a smart detector: a device that can determine whether contraband is present in a manner to which those not carrying contraband cannot reasonably object. Unlike searches of one's home or person that irritate, embarrass, and demean the innocent as well as the guilty, canine sniffs of luggage are an irritation to which only those who are discovered with contraband can object.

Similarly, in United States v. Jacobsen, ${ }^{115}$ the Supreme Court upheld the validity of a field cocaine test conducted without a warrant. Because the test revealed only whether the suspicious substance was cocaine (and not whether it was a prescription drug, sugar, etc.) the Court held that

[a] chemical test that merely discloses whether or not a particular substance is cocaine does not compromise any legitimate interest in privacy .... Congress has decided-and there is no question about its power to do so-to treat the interest in "privately" possessing cocaine as illegitimate; thus government conduct that can reveal whether a substance is cocaine, and no other arguably "private" fact, compromises no legitimate privacy interest. ${ }^{116}$

It is clear, therefore, that the Supreme Court has repeatedly endorsed the proposition that a test which determines nothing about an individual except whether they are in possession of specific contraband is not a search under the Fourth Amendment. By analogy, the Court would likely find that a smart gun detector does not constitute a search under the Fourth Amendment as it, like the dog-sniff or the field cocaine test, would reveal nothing about the individual except whether they were in possession of contraband. Such a device thus offers a possible solution to the quandary of how to search sensibly for handguns in public places. If such a device could be developed, the public could be safeguarded from the risks of concealed weapons at no privacy cost to the innocent.

A smart gun detector need not produce evidence sufficient to convict a person of carrying a concealed weapon. All that is required is a test that, if

114. It should be borne in mind that Place dealt with sniffs of luggage, not of people or their homes. There is a strong argument that the use of dogs to sniff individuals would constitute a search, as it is an indignity to which even the innocent could object. See, e.g., Dow v. Renfrow 451 U.S. 1022 (1980) (Brennan, J., dissenting); Arnold $\mathrm{H}$. Loewy, The Fourth Amendment as a Device for Protecting the Innocent, 81 MICH. L. REV. 1229, 1246 (1983).

115. 466 U.S. 109 (1984).

116. Id. at 123. At least two members of the Supreme Court have seen these cases quite differently. While agreeing that a surveillance technique which reveals only the presence or absence of contraband is less intrusive than other techniques, Justices Brennan and Marshall are unwilling to admit that this alone indicates that the techniques do not involve searches. But they go further; by deciding that such techniques are not searches, they argue, the majority "has foreclosed any consideration of the circumstances under which the technique is used, and may very well have paved the way for technology 10 override the limits of law in the area of criminal investigation." Id. at 137-38 (Brennan, J., dissenting) (emphasis added). 
positive, would give law enforcement probable cause to believe that a crime was being committed and if negative, would give no information about the individual. Further searches could then be conducted in full compliance with the rule in force prior to Terry that where a warrant would be infeasible, searches may be conducted only when based upon probable cause. ${ }^{117}$ The fact that probable cause would be obtained only after the use of the smart detector would not constitute impermissible bootstrapping, as the use of a smart detector is not a search for the purposes of the Fourth Amendment.

\section{Recent Developments: How Close is a Smart Detector to Reality?}

A flurry of excitement on the subject of smart gun detection followed the publication in 1994 of an article by James Q. Wilson in the New York Times, which suggested that gun violence could be controlled in part through the use of advanced gun detectors. ${ }^{118}$ This article created interest among industry, government, and research scientists, ${ }^{119}$ and ultimately led the Department of Justice to grant funds to a number of firms currently working to apply emerging technologies to the detection of weapons. The remainder of this article examines these technologies, discussing their advantages and disadvantages as detection systems, and ultimately whether they would meet the Supreme Court's Place-Jacobsen test for smart-detection.

\section{$\mathrm{V}$ \\ WEAPON-DETECTION SYSTEMS}

The preceding analysis illustrates that a smart weapon detector would save courts from their quandary on weapons searches. A smart detector would allow the courts to do that which they feel compelled to do-allow police to search suspects for weapons and security personnel to search for weapons at points of entry to public places-while at the same time returning searches to the rubric of probable cause. A smart weapon-detector would also minimize the

117. See, e.g., Wong Sun v. United States, 371 U.S. 471 (1963) (stating that the requirements for an officer to act in the absence of a warrant cannot be less stringent than the requirements for a court approved warrant, namely probable cause). 47.

118. James Q. Wilson, Just Take Away Their Guns, N.Y. TIMES, Mar. 20, 1994, § 6 (Magazine), at

119. In addition to the recent grants given by the National Institute for Justice, the research arm of the Justice Department, the following is a partial list of the recent activities in this area: The National Institute of Justice's ("NIJ") Law Enforcement Technology Advisory Council, made up of 85 police executives from throughout the country, listed concealed weapon detection technology as their number one technological priority; the House Armed Services Committee allocated $\$ 37$ million to fund eleven law enforcement technologies, the first of which was concealed weapons detection; the House Subcommittee on Crime and Criminal Justice held a hearing on law enforcement technologies, among which weapon detection was prominently featured; Lloyd Cutler, Council to the President, in his keynote address to the NIJ's Law Enforcement Technology Conference raised the issue of concealed weapons detection and pledged his full support to the project. Letter from Jeremy Travis, Director, National Institute of Justice, to addressee (Oct. 6, 1994). 
opportunity for law enforcement to use weapons searches impermissibly as an opportunity to look for other contraband.

A number of technologies are in the process of being developed to improve the ability of law enforcement to conduct these searches. This section examines each of these technologies in some depth. ${ }^{120}$

\section{A. Imaging}

It has been clear for some time that searching for weapons by searching for metal is an over-inclusive way of finding guns. There is no question that metal detectors work; because most guns are still made almost entirely of metal, metal detectors will generally catch guns. However, they will also catch whatever other metal an individual is carrying. With this in mind, at least two different technologies, back-scatter x-ray imaging and millimeter ("mm") wave detectors, are being developed to search for weapons based upon their distinctive shape rather than on their metallic content. These devices attempt to determine whether an individual is carrying a weapon by creating an image of any objects secreted beneath his or her clothing.

\section{Back-scatter $x$-ray}

a. System operation. The back-scatter $\mathrm{x}$-ray imager works by interrogating the subject with radiation in the $x$-ray spectrum and using the results to create an image. ${ }^{121}$ Unlike medical $x$-rays, however, which rely on the image created by those $\mathrm{x}$-rays that pass through the subject and are collected by photographic cells on the far side of the subject, back-scatter imaging creates an image from the $\mathrm{x}$-rays that are reflected off of the subject and are collected by sensors facing the subject. ${ }^{122}$ Because $x$-rays reflect off of dense objects such as steel at a different rate than off of flesh and because they pass quite freely through most clothes, the outlines of objects carried against one's body can be detected from the pattern of the reflected energy. At least one company in the United States is currently producing a back-scatter imager. ${ }^{123}$

120. This article does not contain an analysis of one emerging technology, an advanced metal detector being developed at the Idaho National Engineering Laboratory. Repeated attempts to acquire information from the laboratory were unsuccessful; there is no non-proprietary information available on the system. The system appears quite similar to metal detectors currently in use in airports, perhaps improving on them by localizing any metal detected on an individual.

121. Interrogation here takes on a meaning distinct form its use in the legal field. In this context, interrogation simply means directing a signal at an object and interpreting the response.

122. One can think of a traditional $x$-ray as analogous to placing your hand over a bright light and seeing the outlines of your bones, which do not allow the light to pass through. Similarly, a back-scatter $\mathrm{x}$-ray is akin to simply shining light on a dark subject and using the pattern of light that is reflected to create an image.

123. The IRT Corporation of San Diego is currently making and selling a back-scatter x-ray imager, the Secure 1000 , for use in entry-exit contexts. IRT sold the first models to the Mexican government for use in maximum security prisons and is currently attempting to sell the system in the United States wherever "stopping the flow of narcotics, weapons and explosives is crucial." IRT RECEIVES FIRST ORDER FOR SECURE 1000(TM) SCANNERS (Jan. 18, 1993) (IRT Press Release on file with author). 
b. Health concerns. The back-scatter x-ray imager is an active system; the subject is bombarded with radiation, and the results are measured. This characteristic is likely to be a major drawback to the system since a public which has been inundated with the cancer risks of radiation will likely react with fear and suspicion to any system that exposes people to $\mathrm{x}$-rays every time they wish to fly, go to court, or enter other public areas. The manufacturer of backscatter $\mathrm{x}$-ray detectors, apparently aware that the word x-ray will set off warning bells with the public, claims that an image can be created at an amazingly low level of radiation: approximately three microrem per scan. ${ }^{124}$ To put this number into perspective, it is equivalent to one percent of the extra daily radiation exposure in a high altitude city like Denver. ${ }^{125}$ As the company's brochure for the system points out, being scanned twice a day for a year exposes an individual to a smaller amount of radiation than one absorbs during a single flight from Los Angeles to New York. ${ }^{126}$ Public opinion is often driven more by fear than reason, however, and the actual radiation exposure may end up being irrelevant to the acceptability of this system by the public.

c. Portability and range of operation. Another drawback to such a system is that, similar to the magnetometers currently in use in most airports, a backscatter $\mathrm{x}$-ray system would require the subjects to pass one-at-a-time through a detector in order to determine whether they are armed. That is, it would be impossible for law enforcement officers operating in the field to use the device surreptitiously to determine whether a suspect is armed. Because the device operates only when the individual is stationary and within a few inches of the detector, the acquiescence if not the active participation of the person being interrogated is required.

Furthermore, production of a portable version of the device is not forseeable. The size of the device must be on the order of the size of the person being scanned so that the entire body can be interrogated with $\mathrm{x}$-rays and the reflected energy measured. If the person being interrogated is not directly in front of the device, the reflected energy will not be picked up by the detector. These technical limitations indicate that any system based on present technology will be stationary and limited to short ranges.

d. Scanning time. Another problem with the back-scatter x-ray system is that the resultant delays would be sizable. While a metal detector can do its job as an individual passes through it at a normal walking speed, the $\mathrm{x}$-ray imager would require each subject to stop and stand still while being imaged. The company currently manufacturing back-scatter $x$-ray detectors states that

124. The Secure 1000 is Safe 2 (1994) (IRT brochure on file with author).

125. Id.

126. Id. 
approximately three seconds are required for each scan, ${ }^{127}$ but the time delays are likely to be much longer. The problem is that unlike medical $\mathrm{x}$-rays, which can "see" through the body, back-scatter x-rays can only see through clothing to reveal features on the surface of the skin. Thus, while taking a medical $x$-ray of an individual would reveal a gun anywhere on his person, imaging the front of an individual with a back-scatter $x$-ray system would not tell the operator whether the subject had a gun in the back of his waistband. In order to make that determination, the individual must turn his back to the imager, and a second image must be taken. Thus, the time required to image an individual is at least six seconds, and realistically closer to fifteen or twenty seconds as the individual must be maneuvered into position and interrogated with $\mathrm{x}$-rays, the image evaluated, the individual turned into proper position, and the process repeated. ${ }^{128}$ This is the minimum amount of time a search can take; unlike current metal detectors, which are virtually instantaneous in producing a negative result (if the buzzer doesn't go off, the individual can continue walking toward his destination), the x-ray imager requires at least six seconds to produce even a negative result.

e. Privacy implications. Clearly the $\mathrm{x}$-ray imaging system would be more invasive of privacy than the current method of using metal detectors. One of the reasons that the public generally does not seem to mind being made to pass through metal detectors is that these detectors are really black boxes. We pass through them and either a buzzer goes off or it does not. Those operating the machine are not privy to any information about us other than whether we are carrying enough metal to activate the detector. As the $\mathrm{x}$-ray imaging system is currently designed, however, an operator must study the image produced to convince himself that the individual is not carrying a weapon. The image, while designed to highlight objects being carried against the skin also produces grainy images of the human body in which the outlines of breasts, buttocks, and genitalia are clearly visible. As it currently exists, therefore, the x-ray imager is a strip-search that does not require the individual to remove his or her clothes. The individual is spared the indignity of being forced to disrobe, but not the indignity of having his or her body examined by a stranger.

The difference between conventional metal detectors and the x-ray imaging system, however, is not so stark. While conventional metal detectors operate as black boxes, they do not operate very well. Thus, a number of people are forced to empty their pockets in public, revealing the contents not only to the operator, but to whomever else happens to be in the area. If the individual again sets off the metal detector after emptying his pockets, he may be subject to a physical search by an officer who places his hands directly on the

127. Id. at 3 .

128. It is not true, however, that as the number of scans goes up, the radiation dose does accordingly. Because the radiation that is being used does not penetrate the skin, imaging the front and the back of an individual does not subject any part of that individual to twice the radiation of one scan. 
individual, usually in full view of passersby. Therefore, if the x-ray imager is able to reduce significantly the number of false positive signals produced at checkpoints, the increased invasiveness of the search itself might be offset by the fact that it subjects fewer individuals to the indignities of having to empty their pockets and submit to a frisk.

f. False negative risks. It would be quite possible for a determined individual to defeat the system by taking some precautions. Because the system relies on the familiar shape or signature of a weapon rather than its metallic content, an individual could successfully defeat the system by changing the shape of his weapon. For example, one could easily break the gun down to its constituent parts-grip, barrel, firing mechanism, and so on-each of which would appear relatively innocuous on the screen. Or, because the imaging system relies on the differential reflexivity of steel and flesh, one could camouflage the weapon by placing it against something metallic or by attaching something else metallic to it. For example, placing a gun in a metal box would create a nondescript mass cloaking the recognizable outline of a gun.

The capacity of evasive measures to defeat the system raises a point applicable to each of the systems to be discussed. None of these systems is foolproof, and any one of them used alone will be vulnerable to a dedicated, knowledgeable individual who wishes to defeat the system. In considering the viability of each system, therefore, we must keep in mind the sort of threats we hope to defeat. If our goal is to help police determine whether street criminals are armed and to allow court personnel to keep angered ex-husbands from bringing guns into courtrooms, it may be quite possible to produce a system that will be a significant improvement on our current methods. If on the other hand, we are concerned with the threat posed by state-sponsored terrorists with the time, expertise, and dedication to defeat detection systems, we will in all likelihood not be able to produce a system that will make us invulnerable to attack. I argue that a far greater threat is posed by the former group than by the latter. Thus, the remainder of this article deals with what can be considered to be the most realistic and commonplace threats posed by concealed weapons.

g. False positive problems. It is difficult to estimate what the false positive rate will be for a system that is not yet in operation; however, if the system works as expected, the false positive rate will be far below that of current metaldetectors. This is true simply because more things are made of metal than look like handguns. With the use of a back-scatter x-ray detector, individuals would no longer be detained for carrying such innocuous items as keys, pens, beltbuckles, and so on.

The false positive rate in operation will depend to some degree on the level of security required. If the location being protected is a prison, an airport, or other area where a single handgun can do a tremendous amount of damage and where there is reason to believe that perpetrators will take complicated measures to avoid detection, the false positive rate may be quite high. A 
number of persons will be stopped not only when objects they are carrying appear threatening but also when operators are unable to make out the object. In other contexts, such as schools or federal office buildings where the threat posed by handguns is less or where there is little indication that those being scanned will be aware of the ways to defeat the system, the false positive rate should be quite low.

h. Usefulness as a smart detector. We have seen that the back-scatter x-ray imager has great potential to detect hidden weapons. The system will likely be able to distinguish between guns and non-threatening metal objects more efficiently than the current system of weapon detection. This does not make it a smart detector, however. A smart gun detector, as discussed in the previous section, is one that tells the investigator nothing about the subject except whether he is in possession of a weapon. While passing through an x-ray imager is unlikely to bring a person with a metal belt-buckle under suspicion as the current system does, the system is only able to distinguish between guns and other objects visually. Thus, unlike the dog-sniff of luggage permitted in Jacobsen, this is a search to which an innocent person could object-one need not be carrying contraband to object to having a stranger examine one's exposed body. As we will see with the next technology, however, there may be a solution to this problem.

\section{MM wave imager}

a. System operation. All objects at temperatures above absolute zero emit radiation across a broad wavelength spectrum. Different objects, however, emit at different rates, depending on both their composition and their temperature. For example, at normal temperatures, the human body is a strong emitter of radiation with a wavelength on the order of a millimeter. This radiation passes freely through most clothing but is unable to penetrate metal. ${ }^{129}$

An mm wave imaging system takes advantage of these characteristics to image the human body. The system is relatively simple, consisting of little more than a receiver of $\mathrm{mm}$ waves and a computer to translate signal intensity into images. The receiver is pointed at the individual being scanned. Parts of the body that are covered only with clothing will emit $\mathrm{mm}$ waves strongly (the waves will pass easily through the clothing and be detected by the receiver), while parts hidden behind metal objects will produce weak signals (the signal from the body will be unable to penetrate the metal). By mapping out the body according to the strength of the signal, the shape of any objects obscuring the

129. Intelligent Vehicle Highway Systems: Hearing before the Subcomm. on Crime and Criminal Justice of the House Comm. on the Judiciary, 103d Cong. (1994) (testimony of Dr G. Richard Huguenin, Millitech Corp.). 
signal can be discerned. Recently, the Millitech corporation received an National Institute of Justice ("NIJ") grant to pursue this technology. ${ }^{130}$

b. Safety concerns. The $\mathrm{mm}$ wave detector solves a number of the problems associated with the back-scatter x-ray system. The first is that the $\mathrm{mm}$ wave system is passive, not active: Rather than bombarding the subject with radiation and using the results to create an image, the $\mathrm{mm}$ wave system simply collects and measures the naturally occurring radiation emitted by all objects. While, as has been argued above, the radiation exposure associated with a backscatter x-ray detector is likely to be quite minimal, ${ }^{131}$ the fact that the $\mathrm{mm}$ wave system is passive rather than active will be a benefit in terms of convincing the public of its safety. ${ }^{132}$

c. Portability and range of operation. In addition to its health advantages (perceived if not real) over the $\mathrm{x}$-ray imaging system, the $\mathrm{mm}$ wave detector also has the benefit of portability and flexibility not found in the x-ray system. Not only can the $\mathrm{mm}$ wave system be used at points of entry much like the x-ray system, it can, at least theoretically, be used in the field as well. Millitech envisions a hand-held detector, about the size of a radar gun, that can be used to scan subjects in the field. The company argues that its smaller detector could also be "mounted on the lightbar of a police car and used for remote, all weather, day/night surveillance."133 Because of the portability, concealability, and unobtrusiveness of this system, it may be possible to search individuals from some distance, even without their knowledge. This would permit a police officer sitting in his police car to determine if a suspect is armed before the individual is even aware that he is under surveillance.

This result will not be easy to achieve, however. The first problem is that the range of a detector varies directly with the size of the aperture of the detector. A device that might be useful at a long range might be prohibitively large for easy transportation: A hand-held detector the size of a radar gun might have a range of only approximately fifteen feet, while a system that would work at forty-five feet would need to be three times the size to provide the same resolution. Thus, there will inevitably be a tradeoff between portability and range of operation.

130. See, Butterfield, supra note 1.

131. See supra text accompanying notes 125-27.

132. There should be no legal difference between an active and a passive imaging system. The difference is akin to the difference between viewing an object in natural light or shining a light on an object to make it clearer. The former relies on naturally occurring radiation, while the latter is an active system. Courts have consistently held that the use of artificial light is not a search under the Fourth Amendment. See, e.g., Texas v. Brown, 460 U.S. 730, 740 (1983) ("[T] he use of artificial means to eliminate a darkened area simply does not constitute a search, and thus triggers no Fourth Amendment protection.").

133. G. RICHARD HUGUENIN, DETECTION OF CONCEALED WEAPONS AND CONTRABAND USING PASSIVE MILlimeTER WAVE IMAGING 6 (Millitech Corporate Brochure on file with author). 
A greater problem than detector size is that like the $\mathrm{x}$-ray system, the $\mathrm{mm}$ wave system would be able to image only the surface of the object facing the detector. Thus, while a sufficiently large detector might give police the range to image a suspect from the relative safety of a passing police car, the officers would be able to image only the side of the suspect facing them. To be certain that the suspect is unarmed, the officers would either have to wait for the suspect to turn around or confront him and force him to turn. In either event, the $\mathrm{mm}$ wave imager will not soon be able to permit instantaneous, discreet, remote searches of individuals in the field.

d. Scan time. Unlike the back-scatter $\mathrm{x}$-ray detector, the $\mathrm{mm}$ wave detector can create an almost instantaneous image of an individual standing in front of it. As noted above, the technology is capable of imaging only one side of the individual at a time. Thus, although the imaging itself is quite quick, a non-negligible amount of time would be required to place the individual before the scanner, take an image, study the image, turn the individual, take another image, study that image, and then make a final determination. Thus a delay of several seconds would be required, even to produce a negative result. While such a delay is relatively insignificant in some circumstances (prisons, for example), this delay would be unreasonable in others. For example, if a high school has 2,000 students and wants to scan them all with detectors located at two entrances, the search would take more than eighty minutes, even if no weapons were detected or suspected.

e. Privacy implications. Because the system "sees" through clothes to create its image, the same privacy concerns are present here as with the $\mathrm{x}$-ray system. The difference in wavelength between $\mathrm{mm}$ waves and $\mathrm{x}$-rays makes the problem slightly different, however. Because $x$-rays have shorter wavelengths than $\mathrm{mm}$ waves, the images the $\mathrm{x}$-rays produce will be sharper. Thus, the details of the human body will be in poorer focus on an image produced with $\mathrm{mm}$ waves than with $\mathrm{x}$-rays. This makes the problem of invasiveness less pronounced, but certainly does not dispose of it. As with the x-ray imager, the question of whether the search is unduly intrusive likely will be answered by the context in which the system is used.

f. False positive problems. As with the back-scatter $\mathrm{x}$-ray system, the false positive rate of the system depends in large part on the requirements of the context in which the system is used. The false positive rate would likely be higher for the mm-wave system than the $\mathrm{x}$-ray system, however, because of the difference in resolution between the two systems. Because the mm-wave system will produce signals that are less sharp, there will be a greater number of ambiguous results, and hence a need to detain a larger number of persons for further search. 
g. False negative problems. Like the $\mathrm{x}$-ray system, the $\mathrm{mm}$ wave system detects weapons based on their shape. Thus, the $\mathrm{mm}$ wave system will be equally susceptible to attempts to obscure the shape of weapons. For example, an individual can defeat detection by placing something between the weapon and the detector that would be opaque to mm waves (anything cool or metallic, even tinfoil, would likely work). Or, by disassembling the weapon into relatively innocuous looking parts, one may defeat an operator who is looking exclusively for the familiar L-shape of a handgun.

Additionally, the $\mathrm{mm}$ wave detector has a unique problem not found with the $\mathrm{x}$-ray detector. The effectiveness of the $\mathrm{mm}$ wave detector depends to some degree on the difference in temperature between the human body and the cooler gun in front of it. If a gun is left in contact with the skin for a sufficiently long time, however, it will begin to approach body temperature and thus begin to emit $\mathrm{mm}$ waves at a rate much closer to that of human tissue. The weapon will still be opaque to $\mathrm{mm}$ waves generated by the body, but it will generate a sufficient amount of radiation itself that it will not be readily discernible from the body. This problem is particularly troublesome, as it means that the system can be defeated not only by an experienced and committed terrorist, but also by any one who has been carrying a weapon in close proximity to his or her body for a significant period of time.

h. Usefulness as a smart detector. While the $\mathrm{mm}$ wave imager might have some advantages over the back-scatter x-ray imager, particularly in terms of perception of safety and range of operation, it is nonetheless a long way from being a smart detector. The main problem, as with the $\mathrm{x}$-ray imager, is that guns are detected visually. Because this visual detection requires the operator to view images that reveal intimate details of the target's anatomy, a scan with either imaging system is an indignity to which even a person not carrying contraband may reasonably object. This puts it in a different category than the canine sniff and cocaine test which have been held not to be searches because they reveal nothing about the individual except whether they are carrying contraband.

The producers of the mm-wave system argue that this problem can be circumvented through the use of "image understanding algorithms." 134 The understanding algorithm, which should be applicable to the $\mathrm{x}$-ray imager as well as the mm-wave imager, would consist of a computer filtering system designed to send only suspicious cases to the human operator for further inspection. In other words, the signatures of a number of known weapons would be stored, and the filter would compare the signal from an individual with the weapons signatures. If the match is close, a buzzer will sound, and there will be probable 
cause to detain the individual for further searches, if there is no match, the individual will be free to go.

This would seem to bring both of the imaging systems very close to the requirements of a smart detector. Assuming that a good computer filter could be designed, a detection system would exist that could produce probable cause to search without invading the privacy of those not carrying weapons.

The problem remains that even with the use of the image-understanding algorithm, a scan with a smart detector might require a seizure of the individual, albeit for the short time necessary to conduct the search. ${ }^{135}$ We have seen that use of either system requires the law enforcement official administering the scan to take control over the individual being scanned in order to position them in front of the detector. This control over the individual will likely be termed a seizure of the individual.

Although the Court in Terry refused to establish the grounds necessary for a police officer to seize an individual to conduct an investigation, ${ }^{136}$ subsequent cases indicate that the same standard applies to seizures that applied to searches in Terry. ${ }^{137}$ Officers must have "a particularized and objective basis for suspecting the particular person stopped of criminal activity."138 Where an imaging system is used in a point-of-entry context, there will, by hypothesis, be no particularized basis for suspecting the particular person stopped of criminal activity, and a court would likely not permit the use of a smart detector if the scan can be accomplished only by restraining the freedom of an individual to walk away. Similarly, in the street interrogation context, a court is likely to hold that stopping a suspect and asking him to turn around to be scanned by the $\mathrm{mm}$ wave imager constitutes a seizure and would thus be permissible only where there are valid and articulable reasons for suspecting the individual.

Therefore, smart detection has another requirement we have not yet considered. Not only must the system identify those carrying weapons without revealing anything else about those being scanned, but it must do so without requiring the seizure of the individual in the process. ${ }^{139}$ Thus, an imaging system can be a smart detector only if it is coupled with an image-understanding algorithm and is capable of completing its scans without delaying those being searched.

135. See Terry v. Ohio, 392 U.S. 1, 16 (1967) ("[W] henever a police officer accosts an individual and restrains his freedom to walk away, he has "seized' that person.").

136. Id. at $19 \mathrm{n} .16$ (pointing out that nothing in the opinion spoke to the "constitutional propriety of an investigative 'seizure' upon less than probable cause").

137. See LAFAVE, supra note $17, \S 9.3(\mathrm{~b})$ at 350.

138. United States v. Cortez, 449 U.S. 411, 417-18 (1981).

139. In a way, this requirement is actually contained in the working definition of a smart detector above-a device must be able to determine whether contraband is present in a manner to which those not carrying contraband cannot reasonably object. 


\section{B. Discriminating Metal Detection}

One solution to the current false positive problems with metal detectors is to narrow the scope of metal objects that metal detectors are capable of detecting. Currently the Raytheon Corporation is engaged in this project and has received an NIJ grant to pursue its work. ${ }^{140}$

1. System Operation. Conventional metal detectors rely on two properties of electrodynamics: Changing magnetic fields induce currents in metals, and currents in metals generate magnetic fields. These detectors generally consist of a portal through which a constantly changing magnetic field is passed. This changing field will cause charges to flow in any metal present in the portal. This current in turn generates new magnetic fields that are detected by the system. The problem with this detection method, as anyone who has passed through a metal detector is acutely aware, is that a number of objects other than guns set off metal detectors. Whenever a magnetic field above a certain threshold is detected, an alarm is sounded; this is a very one-dimensional approach to detection.

What distinguishes the discriminating metal detector from conventional ones is its reliance on a third electrodynamic principle: Charges, once put in motion, will stop moving once the force propelling them is extinguished (much as a car will coast to a stop once the foot is taken off the accelerator). Conventional metal detectors produce a sine-wave signal that is constantly changing. In contrast, the advanced system uses a squared off wave pattern-the signal is constant for most of the cycle. During the very brief time the field is being turned on and off (approximately 10-5 seconds), charges will begin to move in any metal in the portal, and a magnetic field will be induced. Once the external field reaches its steady state, however, charges will have no impetus to move, and the current will die out. The period where the signal is not changing is what distinguishes the advanced system from the traditional one, as it is during this period when currents in the metal begin to die out and their decay patterns are measured. (Note that the periods of changing field are greatly exaggerated for the purpose of clarity. In reality, the field is changing for only a very small fraction of the cycle.)

By measuring not only the strength of the field created but also the rate at which it decays, the advanced system is able to discern threatening and nonthreatening metallic objects. Because it bases its detection mechanism on these two characteristics rather than simply the size of the response, the system can

140. Raytheon COMPany, Equipment Division, TEST and EVAluation of a HaNdGun DETECTION SYSTEM BASED ON ELECTROMAGNETIC TECHNOLOGY 2 (1994) (NIJ grant application on file with author). 
determine both the conductivity ${ }^{141}$ of the metal creating the response and the approximate cross section of the object being interrogated.

Armed with these two characteristics, the detector will be able to place any signal on a two-dimensional grid according to its conductivity and cross-section. Because the conductivity and cross-section of handguns is determinable, the system can compare the signal from an unknown source with the signal a handgun would give off. As with the image-understanding algorithm described above, individuals are detained only if they produce a signal that closely resembles the signal produced by a weapon. Raytheon has done some preliminary tests that show that the machine is capable of distinguishing a ninemillimeter handgun from a twelve-inch adjustable wrench, a ten-inch vice grip wrench, and a twelve-inch steel three-hole punch. ${ }^{142}$

2. Safety Concerns. Because this system is based on technology very similar to that already in place wherever traditional metal detectors are in use, it is likely to raise few safety concerns. Although, as mentioned above, traditional metal detectors are active systems, Americans rightly seem unconcerned by the prospect of walking through these devices. There is no reason why the advanced metal detectors should be seen any differently by the American public.

3. Portability and Range of Operation. One obvious drawback to the system is that it apparently will be limited to the point-of-entry context for the foreseeable future. While Raytheon envisions a detector that could be used on the street, ${ }^{143}$ this seems a long way off. The detector measures very small changes in a known magnetic field, and thus would be easily confused in a street environment by stray fields emanating from everything from power lines to passing cars. In fact, when the system is installed in a point-of-entry context, it must be calibrated to take into account the background signal created by any metal-floor supports, furniture, and so on-that is part of the detector's surroundings. ${ }^{144}$ Such site-specific calibration makes portability seem particularly unlikely.

4. Scan Time. The system has the advantage of being a walk-through detector, which, like conventional magnetometers, is capable of giving a result as an individual walks through it at a normal speed. Thus, unlike the imaging systems described above, the advanced magnetometer would be capable of giving an indication, either positive or negative, as quickly as individuals are able to walk through it. The delays would therefore be no greater (and in light

141. Conductivity is the capacity of a metal to allow a current to flow through it. Different metals such as steel, aluminum, and copper have significantly different conductivities.

142. RAYTHEON COMPANY, supra note 140, at 12.

143. Interview with Charles J. Dyer, Manager, Sonar Systems, Raytheon Corporation, Mar. 3, 1995.

144. Id. (describing the difficulty encountered when initially testing the system). 
of the improvement in false positive rate described below, probably much lower) than the delays currently experienced wherever metal detectors are used.

5. Privacy Implications. Because the advanced metal detector, like conventional metal detectors, works on the metallic characteristics of an object rather than its shape, the privacy problems associated with the imaging systems are not present. The advanced metal detector is essentially a black box. A positive signal is given off only if the signal received from the target matches one associated with a weapon. Any human examination of the detector's signal will reveal only the cross-section and conductivity of any metal the individual is carrying-hardly information likely to embarrass the individual being evaluated.

6. False Negative Problems. Like any detection system, the advanced magnetometer is susceptible to evasion. For example, as with the imaging technologies described above, disassembling a weapon will make its detection much more difficult. A gun that has been disassembled to its component parts will produce a very different signal (actually, a number of very different signals) than the fully assembled gun. To avoid this problem, the signatures of each weapon's component parts could also be identified, stored, and compared with the signal from an individual. This would no doubt result in a greater number of false positive signals, however, as the signature of a gun barrel, grip, or firing mechanism will be much less unique than the signature of the entire gun. More people will be stopped and subjected to further searches and, thus, the increase in target specificity, which is the real advantage of the advanced metal detector over conventional ones, will be lost.

7. False Positive Problems. With any detection system, the false positive rate will be a function of the sensitivity of the detector. If the sensitivity is increased (if more borderline results are treated as positive rather than negative signals), the false positive rate will go up. Since the sensitivity will be highest where the risk associated with false negatives is the greatest, the greater the risk of false negatives, the more false positives the system will produce. The discriminating metal detector is no exception to this rule. ${ }^{145}$ If the detector is configured only to detect a certain number of weapons, the false positive rate should be quite low-as the signal being looked for is relatively unique. If on the other hand, the system is designed to respond to any large piece of metal with the approximate cross section of a handgun or to even smaller pieces of metal which might be the disassembled components of a gun, the proportion of persons wrongly stopped would increase. Even at this higher level of sensitivity, however, the false positive rate from an advanced metal detector would almost certainly be lower than the rate current detectors produce.

145. The sensitivity of the system can be adjusted by varying the maximum distance by which an individual signal may deviate from a stored system without triggering an alarm. 
8. Possibility of Smart Detection. While there are clearly limits on the usefulness of the discriminating metal detector, it comes closer to functioning as a smart detector than any of the other systems we have examined. It solves the privacy problems of the imaging systems by relying, as do current metal detectors, only on metallic characteristics that reveal little or nothing about an individual except whether or not he is carrying a weapon. The system works like the hypothetical image understanding-algorithm by making the first evaluation of whether an individual is armed a yes-or-no question rather than a visual inspection. Furthermore, the system, unlike any of the others we have examined (but like the old-fashioned metal detector), is capable of producing a signal instantaneously. Thus, when using a discriminating metal detector, it will not be necessary to seize an individual to search him, and it will be possible to scan an individual as he walks through a point of entry at a normal speed.

Of course, instantaneous evaluation and a detection system that reveals no personal information about the individual being scanned are not enough to make a detection system "smart." The system need not only be a black box, it must also be right. This is why the conventional metal detector is not a smart detector. Like the hypothetical smart detector, it instantaneously gives a positive or negative signal without revealing anything else about the individual being scanned. The problem is that it returns a positive signal on approximately half of the people scanned while, according to an early study, only a small fraction of one percent of those passing through metal detectors are actually armed. ${ }^{146}$ Because the discriminating metal detector, at least theoretically, will have a much lower false positive rate, it comes very close to meeting the requirements for a smart detector.

This enthusiasm for the effectiveness of the advanced metal detector as a smart detector should be kept in perspective. It is important to remember that much of this analysis is necessarily speculative, as the discriminating metal detector system is currently only in the planning stage. If the system works as intended, however, this technology has great promise.

\section{Vapor Detection}

Another technology being developed to aid in gun-detection is not a new technology at all. It is in fact an adaption of a detection system that has already been developed and is in place to prevent terrorist attacks. In recent years, as explosives have replaced guns as the weapon of choice for terrorists, airports have installed vapor detectors to search for the presence of explosives in packages. Currently, scientists at the Lawrence Livermore National Laboratory

146. See United States v. Lopez, 328 F.Supp. 1077, 1085 (E.D.N.Y. 1971) (showing that only sixteen out of 500,000 people screened were arrested on any charge). 
("LLNL") are attempting to adapt this technology to make it useful in the field of handgun detection as well as explosive detection. ${ }^{147}$

1. System Operation. As the explosives detection system currently works, air around the suspect package is collected with a small hand-held vacuum. Within the vacuum is a piece of filter paper that traps any particles present in the collected air. This paper is then removed from the vacuum, placed in an analyzer, and heated; as the paper is heated, the impurities it has collected are vaporized and carried down a long tube. The particles settle out of the tube according to their molecular weights, and the presence of a particular compound, for instance, the constituents of common explosives, can be detected. The LLNL project is based on the assumption that just as there are particles that are identifiable with explosives, there are compounds that are unique to handgun ammunition or handgun discharge gases that could be detected to indicate the presence of a handgun.

Instead of utilizing a hand-held vacuum to collect the particles and a separate analyzer to determine what is present in the sample, the detector proposed by the group at Lawrence Livermore calls for the individual to step into a phonebooth-like box to be scanned. In this design, air would be drawn over the individual in the box and passed along directly for compound analysis. The system thus combines the two-step process of explosive detection into a single, integrated procedure that both collects and analyzes samples.

2. Safety Concerns. The vapor detection system is a passive system. It simply collects air around the individual being scanned and determines its contents. As such, the system poses no safety concern whatsoever-in the same way that looking at a suspect or listening to him (two other passive detection systems) pose no safety risk, "sniffing" the individual with the aid of this technology would be absolutely safe.

3. Portability and Range of Operation. Needless to say, as the system is currently being designed, surreptitious use of the vapor detector by law enforcement officials operating in the field would be impossible. While the device could be used at stationhouses to search those brought into custody, it will be of no use to officers wishing to determine from the safety of their car whether the suspicious individuals they are observing are armed.

This is not to say that the technology will never be useful in this context. Like any evolving technology, vapor detection is currently experiencing a period of rapid miniaturization. It may someday be possible to reduce the size of both the detector and the analyzer to a single handheld device that could be passed over the individual to instantaneously determine whether he or she is armed. While this would be an improvement in privacy terms over the currently utilized

147. The material in this section is based on conversations with LLNL scientists Brian D. Andresen and Derrick Scott Mathews conducted in March, 1995. 
physical frisk, it would offer the officer little increased protection. No matter how sophisticated it becomes, the device will always have a very short range. It will never be possible to point a detector at an individual across the street and determine whether he is emitting compounds that are associated with handguns: These compounds are simply too transient and disperse too quickly for long range detection to be possible.

4. Scan Time. The advantage of the system being designed at LLNL is that the collection and analysis stages are combined, cutting the time needed to scan an individual from at least two minutes to virtually none. ${ }^{148}$ Nevertheless, the device would still not be able to deliver instantaneous results.

Even assuming the data collection and analysis are virtually instantaneous, the process of securing individuals in the isolation booth for detection, collecting the data, analyzing it, and then readying the device for the next individual would lead to significant delays. Thus, this technology, like the imaging systems described above but unlike both traditional and advanced metal detectors, would be incapable of delivering instantaneous negative results.

5. Privacy Implications. The Supreme Court has ruled that a sniff of luggage by a drug-detecting dog is not a search for the purposes of the Fourth Amendment, ${ }^{149}$ but has yet to decide the question of whether a canine sniff of a person would constitute a search. While that question might be a close one, ${ }^{150}$ the Court's decisions in Jacobsen and Place would argue against a vapor detector scan of a person being considered a search. While an innocent person might be frightened by the prospect of being sniffed and prodded by a large dog or feel embarrassment or outrage at being so inspected, a scan with a vapor detector is not likely to produce such reactions in a reasonable person. Such a scan would be objectionable only to those in possession of contraband, and it is clear that such an objection is not one the Supreme Court is willing to credit.

6. False Negative Problems. It is possible for an individual (and not just a particularly devious one) to defeat a vapor detection system. A carefully cleaned weapon that is well-sealed in an air-tight container will have an emissivity of detectable particles that is virtually nil. Similarly, if it is the gases associated with firing that are the object of detection, a new weapon or one that has not been fired for some time will be much more difficult to detect than one fired that morning. Furthermore, the presence of strong fragrances such as

148. The LLNL group claims that theirs is the only "real-time" vapor detector currently extant.

149. United States v. Jacobsen, 466 U.S. 109 (1984); United States v. Place, 462 U.S. 696 (1983).

150. Justice Brennan, who dissented in Place, has argued that a canine sniff of a person would be a search for the purposes of the Fourth Amendment. See Doe v. Renfrow, 451 U.S. 1022 (1981) (Brennan, J., dissenting from denial of certiorari). 
perfume can mask the much weaker signal produced by handgun-related compounds.

7. False Positive Problems. In addition to these sizable false negative problems, the vapor detection system is likely to have a high false positive rate. One problem is that anyone who has recently used a gun may trigger the detector whether they are currently in possession of one or not. Anyone who has shot or cleaned a gun the same day they are scanned, or who wore the same clothes while shooting, would likely have enough residue on them to set off the detector. This is one of the problems with detecting the vapors associated with guns rather than the guns themselves; it is possible for gun vapors to be present even if the guns themselves are not.

Furthermore, raising the threshold for a positive signal in an attempt to detect guns rather than mere residue will increase the possibility that a new or sealed weapon will slip through the system. As mentioned above, false positive and false negative rates are inextricably linked, and each detection point will have to determine for itself how to best adjust sensitivity to give the proper ratio of false positives and false negatives.

8. Possibility of Smart Detection. Not withstanding the problems and advantages discussed above, the characteristic keeping vapor detection out of the realm of smart detectors is the delay involved; a person must be seized in order to be scanned with the vapor detector. The delays involved are not great nor is the denial of freedom severe, yet the fact that an individual is denied the freedom to walk away would bring this case within the rubric of the Fourth Amendment. While there is the possibility of creating a walk-through vapor detector, such a possibility is years away from reality.

\section{Implications Short of Smart Detection}

The legal argument for the use of a smart gun detector is relatively straightforward: Because a scan with a smart detector is not a search for Fourth Amendment purposes, it may be conducted without probable cause or individualized suspicion. If such a scan is capable of producing probable cause to search or arrest, weapons searches will again comply with the traditional Fourth Amendment doctrine that, wherever possible, searches be done pursuant to probable cause.

As has also become clear, however, there are a number of technological barriers to the immediate operation of smart gun detectors. Those technologies (like the $\mathrm{mm}$ wave imager) that are the most promising in terms of their range, portability, and minimal false negative problems are least likely to be configured as smart detectors, while those that seem readily adaptable for use as smart detectors (like the discriminating metal detector) are so limited in their scope as to make their wide application impractical. This does not mean that until the technologies discussed above can be configured as smart detectors they will have no effect either on Fourth Amendment doctrine or on the detection of weapons. 
In this area of the law, doctrine and technology are inextricably linked, and the existence of these and other new technologies will undoubtedly have a significant impact. The effects these new technologies will have both on attempts to detect concealed weapons and on constitutional doctrine are described below along with tests that should guide courts in assessing the appropriateness of various weapons detection systems.

1. Less Invasive Means. One thing is clear: Less invasive means exist to conduct a number of the searches that courts have already permitted. For example, either of the imaging systems, even without the use of an image understanding algorithm, would be less invasive than the strip searches commonly conducted at prisons. Similarly, in the point of entry context, a discriminating magnetometer would be less invasive than a traditional one because it would create fewer false positives and hence subject fewer individuals to further search. This makes the first test plain: The use of new technologies should be permitted where the new technologies can achieve the same level of detection as the current system with less invasion of privacy.

Notice that I argue that these technologies should be permitted rather than required. While this may seem like a deviation from the traditional rule that searches must be done in the manner that minimizes intrusion, ${ }^{151}$ to extend this rule to emerging technologies would place law enforcement officials in an extremely difficult situation. Prohibiting a high school, for instance, from using a traditional metal detector at an entrance because an advanced metal detector will create fewer false positives will place the school in a serious bind. It will either be forced to use a higher fraction of its tight budget for the more expensive new technology or choose not to search its students at all. Neither of these is an attractive alternative. To avoid imposing this choice on conscientious state actors, a balancing test should be instituted in those situations where it is alleged that a less invasive system could be used in a particular context. This analysis produces a second test: The differential decrease in invasiveness in the proposed system should be balanced against the differential cost increase of instituting the new system.

2. More Invasive Means. A very different situation is presented where a state actor wishes to move not from a more invasive system to a less invasive one, but where it wishes to institute the use of a more invasive system. For example, how is a court to determine whether a courthouse may discontinue the use of traditional metal detectors in favor of a more invasive imaging system? The following formula should be used to determine whether a more invasive method may be substituted for another. Initially, if the use of a system is challenged, the state has the burden of showing that the system is a more effective detector (that is, has a lower false negative rate) than the one it

151. See Part II.A.2 supra. 
replaced. Once it has been shown that the advanced method is more effective at detecting weapons, the court must balance the improvement in detection against the increase in invasiveness.

While it may seem that the two quantities being balanced are highly incommensurable, this balancing test will actually be more judicially manageable than the proposed test for determining whether a less invasive technology should be required or merely permitted. It is exactly this sort of balancing test, measuring the danger posed by handguns against the invasion to the individual, that courts have been doing all along in considering the constitutionality of searches in various contexts.

3. Site Specificity. The discussion of the first two points makes clear that different technologies will be appropriate in different situations; the question will no longer be simply whether a search should be conducted, but rather what means should be used to conduct the search at issue. An imaging system, for example, would be an improvement over a strip search in a high security prison as it would be able to achieve a similarly low false negative rate at a far lower cost in invasiveness. This same technology is a particularly poor substitute, however, for metal detector searches currently conducted in courthouses and public schools. It would greatly increase the invasiveness to which individuals in those contexts are exposed. A closer case is presented by the stop and frisk, however. Being scanned with a $\mathrm{mm}$ wave imager is more invasive than a frisk in the sense that it reveals the details of the human body in a way that a frisk does not. On the other hand, a frisk is more invasive in the sense that it involves the physical search of the human body.

Courts will be forced to make decisions about where and when the different technologies are appropriate. As the search arsenal available to law enforcement increases from the current, rudimentary systems, courts will have an important oversight function; they will be responsible for ensuring that new searches are instituted only where appropriate.

4. Detectors May Be Used Only to Detect Weapons. All of the systems described above do an excellent job at detecting weapons. One problem, however, is that they can also be turned into very good detectors of drugs, counterfeit money, and other contraband. In fact, the imaging systems are pitched by their producers as contraband detectors, capable of detecting not only weapons but drugs as well. ${ }^{152}$ Similarly troubling is the vapor detector, which might be better suited to detecting narcotics than weapons.

It is important that the production of these technologies not be seen as an excuse to expand the grounds on which searches may be conducted. The

152. See IRT'S PERSONNEl SCANNER RECEIVES PATENT; CoMpany SeEs NeW MARKETING OPPORTUNITY (1994) (IRT Press Release on file with author); TESTIMONY OF DR. G. RICHARD HugueNIN BEFORE THE CRIME AND CRIMINAL JUSTICE SUBCOMMITTEE OF THE HOUSE JUDICARY COMMITTEE, THURSDAY, 21 JULY 1994 (1994) (Millitech brochure on file with author). 
argument that searches for drugs can be conducted at the same time as searches for weapons, with no additional inconvenience, delay, or embarrassment must be rejected. It is important to remember that the reason these searches are permitted in the first place is the unique dangers posed by concealed handguns. The fact that the means for conducting these general searches have been improved does not amount to a justification for them. Courts must remain vigilant against the sort of subterfuge discussed above; contraband other than weapons discovered during weapons searches should be admissible in court only to the extent that its discovery was the by-product of a good faith search for weapons and not a pretext for the search itself.

5. Orthoganal Combination of Detectors. While no one weapons detection system is foolproof, a combination of them may be fairly close. As the coupling of the magnetometer and the psychological profile early in the airport context showed, combining different detectors to compensate for each other's faults is a good way to decrease the false negative rate of the overall system. For example, an individual can defeat an imaging system by disassembling his weapon into relatively innocuous components that might not raise the suspicions of a detector. If an imaging system is combined with a vapor detection system, however, the individual not only would have to disassemble his weapon into several pieces but seal each of them sufficiently to avoid vapor detection. Those areas, airports, prisons, etc., where the threat of weapons is particularly severe could increase protection, not by resorting to ever more invasive searches, but by layering less invasive ones to compensate for the flaws of any single detection system alone.

6. Street Context Most Difficult. A final point is that it will be much more difficult to design a detector for the stop-and-frisk context than for the point of entry context. A system that may work in a controlled setting such as a portal is much less effective in the ever-changing street environment. Magnetic detectors will be thrown off by stray fields from powerlines, passing cars, cellular phones, and the like. Breezes and stray odors will play havoc with any system designed to detect guns based on the vapors they emit. Imaging systems, capable of imaging only the front of an individual, will be of little use to a police officer sitting in a car, wondering if the suspect with his back to the car has a gun in his belt.

This failure of technology to aid in the street context is ironic, because it is clear that the street context is the driving force behind innovation in gun detection. The excitement generated by improved detectors has not been directed at improving searches in the point-of-entry context; rather it has focused on the street context. In his article entitled "Just Take Away Their Guns"153 - the article credited by President Clinton for triggering the interest

153. Wilson, supra note 118. 
in advanced gun detectors ${ }^{154}$-James Q. Wilson focuses on removing guns from the hands of criminals through proactive police action rather than by detecting guns carried into protected areas.

\section{VI \\ CONCLUSION}

The concealed handgun has occupied a unique place in Fourth Amendment jurisprudence for the last thirty years. The dangers posed by highly destructive, easily concealable weapons have led the courts to make specific exceptions to their search and seizure jurisprudence in order to permit searches for handguns. In doing so, the courts have been constrained by the currently available technologies; the outcomes they produced were disappointing not because of any problems with the search doctrines they created, but rather because technologies did not exist that would permit the narrow searches for weapons that the courts were permitting.

All of this is changing. In recent years, there has been a push to create alternatives to the traditional methods of searching for weapons. These technologies hold great promise in the field: They can protect officers attempting to conduct searches; they can minimize the intrusion upon lawabiding citizens; and they can limit the ability of law enforcement to use searches for weapons as pretenses for general contraband searches. However, the technologies are not without problems. They will present difficult problems for judges forced to determine the scope and range of permissible searches for weapons in light of an ever-changing technology.

154. Butterfield, supra note 1. 